\title{
Destigmatizing direction of psychologist's work in the field of mental health care
}

\author{
Olena Malyna \\ Zaporizhzhia National University, Zaporizhzhia, Ukraine
}

\begin{abstract}
Introduction. Currently one of the main directions of the World Health Organization's mental health program is the problem of overcoming the stigmatization of patients with mental disorders. It is particularly relevant in conditions of exacerbation of social relations and increasing of social tension when mentally ill people become the most vulnerable category of stigmatization as a negative and biased reaction to their psychiatric diagnosis and connected with it prejudgment, depreciation, alienation and, after all, discrimination. The introduction of socially oriented types of assistance to mentally ill patients requires a practical solution of the problems connected with sociopsychological rehabilitation of patients with mental disorders, the realization of which, first of all, is provided for overcoming the stigmatization and autostigmatization of people with psychiatric status.
\end{abstract}

Purpose. In Ukraine there are more than one million people who suffer from mental disorders and there is a worldwide tendency to this number growth. The stigmatization of mentally ill people becomes one of the most acute social problem which requires systematic, coherent understanding of the common interdisciplinary foundations of a task-oriented reformation of mental health care system which should be based on the principles of humanism and social justice, and on the implementation of a complex antistigmatization approach to social, psychological and medical help. So, the purpose of the article is to examine the essence and the main features of the destigmatizing direction of the psychologist's work in the field of mental health care.

Methodology / Approach. Despite the social significance of the problem and the pendency of theoretical issues, the separate studies of the influence of the sociopsychological factors on the perception of the mental health and the problems of the attitude of the society towards the patients with psychiatric status saw the light only at the end of the last century (Kabanov M.M., Abramov V. A., Mendielievych V.D., VO Chakhava, Avedisova V.I., Hurvych I.N., Yastriebov V.S., etc.) $[1,3,4,6]$. Traditionally the problem of stigmatization of the mentally ill people has been studied mainly in sociological and medico-social aspects (Hoffman's theory of spoiled identity, 1963; T. Sheff's "label" theory, 1966; Haghighat's unitary theory of stigma, 2001). So, the mechanisms of stigma's formation as a social stereotype (J. Townsend, 1979) and different social factors of the formation of stigma of mental disorder (A. Finzen, S. Sotang, K. Jones) were examined; social consequences of stigmatization (A. Tasman, 1992; J. Crocker, 2004, S. Dinos, 2004), the meat of stereotypes and ideas of different social groups towards the mentally ill people (J. Bright, 1997; J. Rabkin, 1974) were empirically determined; the influence of mental disorders on delinquent behavior (Korolov V.V., Karpets I.I., Kudriavtsev V.N.) was investigated. The mechanisms and ways of destigmatization in the context of a person-oriented model of psychiatric care were developed by such Ukrainian researchers as Abramov V.A., Riapolova T.L., Maruta N.O., Abramov O.V. [1,2,5]. However, there is an obvious shortage of systematic psychological studies of the process of formation of stigma of mental disorder, of factors and mechanisms of self-stigmatization of mentally ill patients of different nosological groups and of psychological technologies of destigmatization.

Results. Stigmatization is the result of social ascription, the projection of society's perception of unacceptable traits or patterns of behavior into an individual. Stigmatization, as a process of isolating an individual from the group (due to its deviation 
from the average norms), allows the group to have a stereotypical set of negative social reactions and, eventually, to realize the purpose of such ascription, namely to use certain social sanctions. So, there should be two conditions for stigma to appear: a parameter that discredits a person and his differences from the dominant social norm and a negative assessment of this difference by the group. These conditions lead to the evaluation of the person completely by this parameter, ignoring his integrity, personality and, eventually, dehumanizing his identity. The need for stereotypes is conditioned by the attempt to explain and justify a negative attitude towards mentally ill people, to rationalize their discrimination.

Destigmatization measures should be, first of all, aimed to overcome and to prevent the factors of stigmatization which include: 1) stereotyping of mass consciousness, manipulation of the public opinion about patients with mental disorders that are traditionally thought to be incompetent, unpredictable, dangerous, helpless, unreliable, disgusting, hostile and those which should be excluded from public life; 2) formation of a negative image of the system of psychiatric care and its opportunities in the treatment of mental disorders in general; 3) too low level of psychiatric and psychological literacy in the society which leads to the formation of negative stereotypes and to the existence of myths about mental disorders; 4) confidence in the low social significance and usefulness of patients with mental disorders, considering them as helpless, dependent and incapable; 5) a low level of social demand of patients with mental disorders, their social isolation and the isolation of their families; 6) a low level of tolerance, empathy, the desire to distance oneself from the mentally ill people and exclude them from social interaction; 7) the discrimination of patients with mental disorders, a lack of job quotas in the labor market, a lack of training and retraining opportunities, complications in the process of rehabilitation and self-realization of patients due to the changes in socio-economic situation in the country.

When psychologist works directly with patients and their families that are stigmatized, he should be aimed to 1) form a stable and consistent self-concept, help to reveal patient 's resources, life goals and build their future perspectives; 2) correct the inadequate attitude and perceptions of their mental state, limitations and possibilities; 3 ) actualize healthy components of mental activity, increase patient's self-esteem, correct patient's destructive identity; 4) correct negative emotional experiences and internal conflicts, form the skills of emotional self-regulation and emotional support within a family; 5) form a coordinated motivational system and mobilize the efforts to overcome the limitations caused by mental disorders; 6) create new behavioral strategies for achieving goals and overcoming auto-stigma and self-isolation; 7) form constructive identity of the mentally ill person.

Practical / Social value. The implementation of socio-oriented types of assistance to the mentally ill people cause the need for further theoretical and empirical study of the problem of stigmatization which will allow to make the program of antistigmatization intervention better, to optimize social integration of patients with psychiatric disorders, to improve the system of their social care and psychological maintenance, to contribute to the effective solution of problems connected with rehabilitation of patients with mental disorders.

Conclusions. Destigmatization, as a process of mitigating of the impact of the stigma of psychiatric illness and prevention of deformation of the personal and social identity of patients, should take into account the principles of activity and publicity, it should have a clear personal and value-humanistic orientation and be focused on the existentially personal rehabilitation of patients, recurrence of their capacity to realize their professional and social potential, restoration of their social status, subjective well-being and quality of life. 
Keywords. Stigma, stigmatization, mental health, discrimination, destigmatization, social distancing, future perspective, identity, patients with mental disorders.

\section{References.}

1. Abramov V.A. Эffektы sty`gmaty`zacy`y` y` autosty`gmaty`zacy`y` bol`nыx na razly`chnыx stady`yax shy`zofreny`y` V.A. Abramov, T.L. Ryapova, A.V. Abramov// Ukrayins`ky`j visny`k psy`xonevrologiyi. - 2008.- \#2 (55). - S. 27-32

2. Gurovy`ch Y`. Ya. Socy`al’naya psy`xology`ya zdorov`ya/ Y`.Ya. Gurovy`ch// Russky`j medy`cy`nsky`j zhurnal. 2001. T.9 \#25, - S. 38-51..

3. Eny kopolov S.N., Meshkova N.V. Napravleny`ya y`ssledovany`ya predubezhdennosty` v zapadnoj psy`xology`y` mezhgruppovыx otnosheny`j. / S.N. Eny`kopolov, N.V. Meshkova //Voprosu psy`xology`y`. 2007, - \#1 - , S.148-158.

4. Kabanov M.M., Burkovsky`j G.V Redukcy`ya sty`gmaty`zacy`y` y` dy`skry`my`nacy`y psy`xy`chesky` bol`nыx. ./ M.M. Kabanov, G.V.Burkovsky`j// Obzor psy`xy`atry`y`y medy`cy`nskoj psy`xology`y`. 2000, - \# 1, - S 3-8.

5. Maruta N.O., Abramov V.A, Ryapolova T.L., Abramov O.V. Sy`stematy`zaciya peredumov i mexanizmiv formuvannya sty`gmy`u xvory`x na psy`xichni rozlady`. Metody`chni rekomendaciyi/ N.O. Maruta, V.A. Abramov, T.L. Ryapolova, O.V. Abramov// DNMU im.. M. Gor`kogo, 2011, 28 s.

6. Phelan J, Link BG, Dovidio JF. Stigma and prejudice: one animal or two? Social Science \& Medicine.2008; 67:358-367 